\title{
E-Communication and Customer Satisfaction: a Case of the Mobile Telecommunications Industry in South Africa
}

\author{
Dayaneethie Veerasamy*, Jeevarathnam Parthasarathy Govender \\ Durban University of Technology, Durban, South Africa \\ veerasamyd@dut.ac.za*, govendej@dut.ac.za
}

\begin{abstract}
Electronic communication (e-communication) refers to communicating by electronic means, especially over computer networks. Organisations use the internet to distribute valuable content in a variety of ways including e-newsletters, articles, videos, webinars, chats, live online events, social networks and forums. Customer satisfaction measures how well the expectations of a customer concerning a product or service provided by an organisation have been met. Customers can be satisfied with more than just the organisation's product offerings. Customers use the Internet to search for general information, instruction guides or tips that they consider interesting or valuable. They often base their buying decisions on what they find. Valuable content can result in positive advertising as customers share positive content-related experiences with others. It can also increase loyalty as customers start to view or perceive an organisation as an expert about industry-related topics. This paper examines the relationship between e-communication and customer satisfaction within the mobile telecommunications industry in South Africa. This research was quantitative, descriptive and cross sectional in nature. The study found that e-communication was being used by the majority of the service providers in the mobile telecommunications industry and that it led to increased customer satisfaction.
\end{abstract}

Keywords: e-communication, customer satisfaction, mobile telecommunications

\section{Introduction}

Since organisations operate in a competitive environment that is dynamic, they need to ensure that they are able to satisfy and retain customers. Marketing communication can be used to influence customers. Customer satisfaction ranks high among the priorities of any organisation. These organisations are always in search of new tactics to meet the expectations of their customers and to increase their levels of satisfaction. They are working on the premise that an extremely satisfied customer buys more than a customer that is just satisfied. E-communication allows people to interact in different ways and combine many forms of media in the process. E-communication makes it easy to interact with groups through chat interfaces or video conferencing. E-communication allows customers to communicate with the organisation more efficiently. Ecommunication allows an organisation to combine text, graphics, sound and video into a single message tailored to a specific audience. It also creates a new form of many-to-many communication that lets geographically distributed groups communicate interactively and simultaneously through text, sound and video. Improving customer satisfaction is one of the main goals of e-communication. Increasing customer satisfaction leads to increased income and profit. This paper examines how e-communication is being used by service providers to positively influence customer satisfaction in the mobile telecommunications industry in South Africa.

\section{Literature Review}

Du Plessis, Strydom \& Jooste (2012) explain that when a sender and receiver exchange messages via a signal system, this is e-communication or digital communication. Digital channels and information technology are changing the way in which organisations communicate, and build and maintain relationships with their customers. Digital communication channels such as the Internet, e-mail, mobile phones and digital TV present organisations with endless opportunities for cost-effective, personalised and interactive communication with their target markets. Digital channels offer the benefit of organisations being able to identify individual customers and collect information from and about them, and then to personalise communication for them. This in turn builds loyalty as communication rather than persuasion becomes the foundation of customerfocused marketing. The digital environment also offers convenient opportunities to organisations to move from one-way to interactive communication. According to Johnston, Clark and Shulver (2012), many organisations have restructured their operations to provide electronic-based services for their customers and 
suppliers. E-commerce has challenged traditional business models and has created new ways of assessing customers and providing different customer experiences. It also gives customers much more control, as information, such as prices and services offered, is more transparent. The benefits that accrue to the service providers are direct access to customers, opportunities for local businesses to become global and build their brands, making information available to customers and linking services.

Stokes (2011) explains that "marketing is about conversations, and the internet has become a hub of conversations", supporting the idea that through the interactive use of the internet, an organisation is able to follow and track the conversations between itself and its customers. This assists the organization to keep up to date with new trends and create an awareness of the changing needs of its customers. According to Theodosiou and Katsikea (2012), organisations, which attained higher-level electronic business performance expansively, utilised the internet to a greater extent to complete various actions to add value to the product or service. Woon-Kian, Shafaghi, Woolaston and Lui (2010) reinforce the growing awareness of the value of emarketing and its impact on changes within the relationship between the consumer marketers and the consumer. Their findings support the belief that e-marketing improves business processes while strengthening the awareness in new markets of the organisation. The influence of the Internet and its tools can be seen in some form in virtually every business. Therefore, marketers need to take advantage of the opportunities offered by the Internet. With the Web, marketers can now embrace an electronic version of the marketplace. It allows providers a fresh sales channel, new methods of advertising, new ways of communicating and an innovative means of creating customer relationships. It has also facilitated the customisation of offerings to suit individual customers and helped improve service delivery. Marketers will have to prepare for the world of the new 'customer of power' of the digital era and learn how to use the marketing and communications tools of this era effectively. Digital marketing endeavours not only to provide information but build and maintain customer relationships through online (digital) activities. Digital marketing is distinct because it is interactive and unique in nature. It rejects the "one message fits all" philosophy of mass media communication. With digital marketing, information is collected using sophisticated multimedia channels, which encourage customer interaction and feedback (Koekemoer, 2011).

A study by Harridge-March (2004:297) reflects that e-marketing will not substitute conventional marketing but observes that it is a helpful and supportive activity. Harridge-March (2004:297) further suggests that the new technology must be included by managers with the intention that customers will then receive superior value. Similarly, Hamidi and Safabakhsh (2010:365) investigated the effect of information technology within e-marketing. The collection of data was accumulated in various ways including a questionnaire to suppliers, designers and users of e-marketing. Financial statements were analysed from companies and government agencies and also information was gathered from the various related literature. The findings confirm that information technology has brought about the following effects. Firstly, information technology creates an opportunity for advertisements to be directed at any time of the day or to any location. Secondly, information technology enhances possible advertising opportunities. Thirdly, information technology enlarges the firm's income and reduces pollution and energy consumption. The advantages of e-communication as described by the MEAM Editorial Team (2013) arequick transmission since it requires only few seconds to communicate, extensive coverage since the world has become a global village and communication around the globe is instantaneous, saving of time and money as it allows immediate feedback. The evolution of electronic media has resulted in managers easily controlling their global business operations via video or teleconferencing, email and mobile communication.

Chipp and Ismail (2012) discuss the advantages of online communication. The Internet provides consumers with round-the-clock access to information; more relevant information is provided since the communication is sent to customers who are interested in the offering rather than those who will probably just ignore the message; online advertisements are flexible and adaptable and can be fine-tuned to suit the preferences of the target audience; it facilitates direct transactions; excellent production quality and it is interactive. The disadvantages of using e-communication is that people are bombarded with so much of data that it becomes difficult to take it all in within a short period of time; high development costs since there is infrastructure to consider; the need for more investment since changes in technology happen very rapidly; the legal considerations and data that does not get distributed because of a system error or issues with technology (MEAM Editorial Team 2013). Du Plessis, van Heerden \& Cook (2010) explain that in order to cultivate an 
integrated style of marketing, interactive digital communication tools must be used. Marketers must keep in mind that consumers will use any media that is convenient to communicate access and transact with the organisation. The benefit of the Internet, SMSs, blogging, social networking sites and the Worldwide Web is that communication is interactive and not limited by physical and time constraints.

According to Strauss and Frost (2014) by using, the Internet individual users have access to information, entertainment, networking, and communication, which is also convenient. Consumers use the Internet to do product and price comparisons, look at product reviews posted by other users on Facebook and SNSs. Consumers also download music, movies and other types of entertainment directly to their personal computers (PCs), iPads and televisions. This can be done at their convenience on the device of their choice. Multi-media, personalised communication is also possible via the Internet. This influences the manner in which individuals work, communicate, and consume. This provides a great opportunity for marketers to provide value offerings to satisfy these individuals while earning a profit. Chipp and Ismail (2012) explain the opportunities provided by the Internet are two-way interactive communication; real-time adjustments can be made; real-time dialogue is possible; offers a new way for customers to initiate contact with the company; companies can follow-up on customer suggestions; companies can use the two-way approach to help develop new products and services and allows companies to personalise customer service. Statistics show that there were approximately 150 million individuals using mobile devices to access the internet in Sub-Saharan Africa (SSA) in 2013. This translates to an overall mobile internet penetration rate of only $17 \%$ of the total population. The average figure for mobile internet penetration worldwide is just over $30 \%$. By 2020 , the rate will increase to $38 \%$ and 240 million more people across SSA will have mobile internet access. The following difficulties are experienced with extending mobile internet access in SSA. There is the issue of cost; high levels of poverty and network coverage in rural areas with insufficient infrastructure. This is a huge concern since 70\% of the population are living in rural areas (The Mobile Economy 2014: Sub-Saharan Africa Report).

Buttle (2004) states that company websites can also be a good source of or for new customers. Anyone with access to the Internet is a prospective customer. The Internet enables prospective customers to search globally for products and suppliers. Berndt and Tait (2012) explain that websites serve as a marketing channel for the organization they represent and they are increasingly being used as virtual stores where customers can shop and buy products. On the other hand, websites also serve as an interactive communication channel for customers to ask questions, state their views, share opinions and, if necessary, to complain. As a marketing and shopping channel, the web offers powerful touch points for the customer when doing business with a company. The web also facilitates the automation of many tasks (such as paying accounts or lodging a service request). According to Berndt and Tait (2012) e-mail is probably one of the most common means of business communication in the modern world. The main benefit of e-mail is that it is a very cheap form of communication. In addition, an increasing number of customers have e-mail addresses. E-mail is quick and easy to use. E-mails can be stored, forwarded to others, replied to and may even include digital attachments. E-mail may be used in conjunction with call centres and websites to extend the reach of a company and to offer an alternative way to communicate with customers. E-mail is an attractive marketing communication tool because it is convenient, not difficult to use and facilitates interaction with the customer. Also, messages can be aimed at specific customers, it is cost effective and it has a worldwide reach since the response can be immediate and quantified (du Plessis et al., 2012).

The manner in which organisations engage with and relate to their customers has changed considerably because of mobile technology. The introduction of tablets and smartphones has changed the way customers read, learn, work, and connect with each other. These devices have become an integral part of society. So much so, that marketers need to find a way to present their offerings in this space. A mobile platform allows an organisation to connect with people via their offerings and their content. By using mobile technology and digital publishing, organisations can distribute information and publish content quickly to multiple devices. These digital editions are an influential and resourceful way to communicate with a rising audience. With digital publishing, magazines, catalogues, sales tools and annual reports become an appealing experience created for the reader (Sloan, 2014). In 2015, the Mobile Africa study was conducted by GeoPoll and World Wide Worx. They investigated mobile phone usage in five African countries (South Africa, Nigeria, Kenya, Ghana and Uganda). The major finding was that Internet browsing via phones is $40 \%$ across these markets. With regards to using their mobile phone to access the internet, results showed $51 \%$ of respondents in Ghana, 
$47 \%$ in Nigeria, $40 \%$ in South Africa, 34\% in Kenya and Uganda are the lowest at 29\%. When looking at app downloads, South Africa is the leader, with $34 \%$ of mobile users making downloads from app stores. This is usually an indication of higher smartphone adoption. In terms of app downloads for the other countries, Ghana is at $31 \%$, Nigeria $28 \%$, Kenya $19 \%$ and Uganda $18 \%$. This study also found that mobile broadband infrastructure is stronger in South Africa (Staff writer, 2015).

Social media (Hanna, Rohn and Crittenden, 2011) have transformed Advertising and promotion. It has also had an effect on consumer behaviour. Social media guides the way in which consumers gather information about products and services all the way to their actions after they have made a purchase. Therefore, marketers need to take advantage of this opportunity and use their social media websites to engage and interact with potential consumers and build strong relationships (Mersey, Davis, Malthouse and Calder, 2010). In order to set their organisation apart from competitors, marketers can use online communication to highlight the benefits and positioning of their offering. While marketers may be assertive about promoting only one advantage in the market concerned, they can use their online presence and social networks to appeal to consumers. It is clear that social media is more efficient than traditional communication channels therefore organisations participate in Facebook, Twitter and Myspace in order to flourish online (Ioanăs and Stoica, 2014). In 2008, Cone Inc. conducted a social media study. The results showed that $93 \%$ of social media users deem it necessary that the companies that they purchase from should have a presence in social media. $85 \%$ think that a company interacts with its consumers via social media. $56 \%$ of users indicated that they interact better with companies who have a social media presence. Therefore, marketers err when they consider a social medium as a mere connector since this medium becomes the means by which marketers connect with connectors and for connectors to link up with each other. In this way, they can share their thoughts and start conversation with society at large (Giannini-Jr, 2010:157).

Stelzner (2009:14) conducted a study that indicated that $81 \%$ of the companies created more publicity for their organisation from their social media activities, $61 \%$ of them saw an increase in customer traffic, in $56 \%$ there were new business partnerships and $45 \%$ of the companies reported a decrease in their marketing expenses. A study by Zabin (2009) identified the effects of social media marketing for three types of companies, depending on the degree of their adoption of social media. The study found that the experience of the $20 \%$ top performance scorers engaging Web 2.0 applications as a marketing tool enhanced the chances of customers recommending the firm's offering in $95 \%$ of the cases. While $87 \%$ of the cases showed an improvement in the return on marketing investment and improved the customer acquisition rate in $95 \%$ of the cases. Marketers use social media for their promotion function. This appeals to social media users and it prompts them to participate. Present day consumers require a different kind of involvement so traditional marketing communication does not work. Therefore, social media marketing presents an innovative way to create and maintain long lasting relationships with consumers. The web and social media marketing have replaced traditional marketing. Marketers now have the opportunity to use different methods to reach their target audience. Marketing is no longer limited to products and services; it can now influence social change through connecting with customers. It is clear that relationship marketing for the Facebook generation demands both thinking and acting differently (Sri Jothi, Neelamalar \& Prasad, 2011).

Clark and Melancon (2013:138) explain that social media is fast becoming a popular way to communicate with consumers. Statistics revealed that $92 \%$ of marketers are using Facebook, 84\% are using Twitter, 71\% are using LinkedIn, $68 \%$ are using blogs and $56 \%$ are using YouTube. As a result, spending on social media is increasing and the number of employees and hours firms dedicate to connecting with consumers via social media is also increasing. Studies show that consumers who participation in an organisations social media strategies share a better relationship with that organisation. The organisation benefits since followers feel that the organisation is making a greater investment in their relationship. They see their relationship with the organisation as being of a higher quality than that of non-followers. Therefore, satisfaction, word of mouth advertising, and loyalty are all higher for followers of social media than non-followers. In the last few years, companies have noticed a change in the relationship with their customers. As communication methods have evolved, customers now have more control and say over the company's offerings. Customers are essential to any business and social networking provides an opportunity for the business to create and maintain even closer and more rewarding relationships with their customers. Therefore, companies need to respond to this change so that they can benefit by using social networking in their marketing. They can also get a better 
understanding of their customer needs and wants, which will improve relationships with their customers. Social networking can also change the way companies consider their customers. They can use customer relationship management to overlap with social networks. These social networks provide ways for companies to connect with their customers. Combining social networking and marketing makes it easier for companies to follow their customers, achieve their goals and control and measure their activities (Assaad et al., 2011:13).

The SA Social Media Landscape report (2015) found that Facebook is the first SNS in South Africa that has equal number of male and female users (5.6 million for each) The South African market still shows a slight male bias when it comes to the use of the Internet so this finding emphasises the degree to which social media has become mainstream. According to this report, Facebook remains the most popular SNS in South Africa, followed by YouTube and Twitter. Of a total of 11, 8-million South African users (22\% of the population), it was found that 8, 8-million access it on their mobile phones. Du Plessis et al. (2012) describe customer satisfaction as a "customer's positive evaluation of the performance of product or service when compared to his or her expectations". Maintaining customer relationships, creating loyalty, retaining customers becomes easier when customer satisfaction is high. When customer satisfaction is low or non-existent, organisations have no chance of creating customer loyalty and retaining their customers. Harris (2014) defines customer satisfaction as the "customer's overall feeling of contentment with a customer interaction". Satisfaction can develop quickly or take a long time to develop if customers have any concerns. Satisfaction could also be a 'customer's afterthought.' This can happen when a customer reflects on the experience and rates it in terms of how pleasant or unpleasant it was. Satisfaction is defined as the 'customer's fulfilment response' and they go on further to explain, "It is a judgment that a product or service feature, or the product or service itself, provides a pleasurable level of consumption-related fulfilment" (Zeithaml, Bitner and Gremler, 2013). The customer will assess the offering according to whether it has met his/her needs and/or expectations. Failure to meet these needs and/or expectations will result in dissatisfaction.

Ercis and Rasouli (2013) maintain satisfaction plays a key role in the success of an organisation. As soon as an organisation starts a relationship and interacts with the customer, satisfaction comes into play. Therefore, it is vital that organisations/firms assign substantial resources to measuring and managing customer satisfaction. To have a close relationship with the customer, the organisation must be fully aware of his/her needs and wants. Rizan, Warokka and Listyawati (2014) explain that satisfied customers are less likely to move to a competitor. If a customer is in a fruitful relationship, there is a greater likelihood for loyalty. A highly satisfied customer will stay loyal for a longer period of time, will purchase more, will have complimentary things to say about the organisation, will pay little or no attention to competitors and is less costly to do business with than new customers. Satisfaction is the result of customers' overall assessment of their perceptions of the service compared to their prior expectations. These perceptions could be about the service process itself, their overall experience, the quality of the products used and their perceived value for money. When perceptions of the service are equal to their expectations then customers should be satisfied. If perceptions of the service exceed their expectations, customers will be more than satisfied, even delighted. If perceptions of the service do not meet their expectations, customers may be dissatisfied, even disgusted or outraged (Johnston et al., 2012).

In view of the ever-increasing competition in the mobile telecommunications industry in South Africa, relationship marketing is applicable when developing enduring relationships with customers because the services on offer from the various service providers are fairly alike and it is not easy to tell the difference. Ndubisi (2004) reported that increasingly firms are taking advantage of the strong firm-customer relationship to gain invaluable information on how best to serve customers and keep them from defecting to the competition. Hence, customer relationship building generates returns for both parties and the firm can obtain quality sources of marketing intelligence, which will assist in better planning. Customer satisfaction is defined as a "customer's overall evaluation of the performance of an offering to date" (Ercis \& Rasouli, 2013). When customers are totally satisfied, it impacts positively on customer loyalty. Example of this in the telecommunications industry is provided by Bolton (1998:61) who found a positive outcome on customer satisfaction for the duration of the relationship for cellular phone customers, and Bolton and Lemon (1999) who indicated a positive outcome on satisfaction for customer usage of telecommunications subscription services. It has been established that increased customer satisfaction can lead to loyalty. Marketers can use social media to address their customer service issues and this can raise their customers' satisfaction to 
greater heights. Since social media allows customers to express their views as well, any issues with the organisation can be resolved timeously (Krishna, Dangayach, and Jain, 2011). The perks for customers who join via social media include special offers, discounts, entertainment, or personal interaction with the organisation and other customers.

The study conducted by Ndubisi, Malhotra and Wah (2009:8) suggests a strong link between the dimensions of relationship marketing dimensions with customer satisfaction and the link between customer satisfaction and customer loyalty. The study also showed an indirect relationship using customer satisfaction between the dimensions of relationship marketing and customer loyalty and a direct relationship between the RM dimensions and customer loyalty. On the whole, the results for this study pointed towards the indirect effect of RM variables on customer loyalty (via customer satisfaction) being a better model than the direct effect. This could be as a result of the higher percentage of variance in customer loyalty. It is very clear that customer loyalty is a good gauge of return on relationship. This is supported by the concept of the 'lifetime value of customers,' and by the notion that it costs way more to acquire a new customer than it is to retain an existing one (Gummesson, 1999). Gummesson (2004:141) defines return on relationship (ROR) narrowly as the "long-term net financial outcome caused by the establishment and maintenance of individual customer relationships."

The study conducted by Boohene and Agyapong (2011:236) in the telecom industry discovered that more often than not, customers will continue with their service provider if there is a high level of service quality. This indicates that here is a positive relationship between service quality and customer loyalty. The study concluded that for customers to be loyal, telecom firms must provide "appealing sales points, wide coverage, and neat, comfortable and convenient office locations as well as being responsive to their requests." However, focusing on customer satisfaction is also necessary as it might enable the firm to cater for some important aspects of the services e.g. switching cost and complaint handling. This study also indicated that the quality of service is the most significant factor in obtaining customer loyalty. The implication for the management of telecom is that they need to emphasise service quality. For telecom, it means that they have to analyse and improve their relationship with their customers since there is no tangible product involved. In order to do this the management of telecom should invest in training and developing their staff in the areas of customer service, customer satisfaction and loyalty and relationship marketing skills. This will lead to the building of a customer-oriented organisation. Staff will then be in a position to provide efficient and effective service delivery. Also staff will be aware that securing and keeping customers is the crux of relationship marketing. Other issues for gaining customer loyalty for telecom includes "confidentiality in transactions, trust worthiness of staff, and availability of customer care centres on weekends, extension of working hours, and provision of security for customers' transactions."

Stokes (2011) explains that "marketing is about conversations, and the internet has become a hub of conversations", supporting the idea that through the interactive use of the internet, an organisation is able to follow and track the conversations between itself and its customers. This assists the organization to keep up to date with new trends and create an awareness of the changing needs of its customers. According to Theodosiou and Katsikea (2012), organisations, which attained higher-level electronic business performance expansively, utilised the internet to a greater extent to complete various actions to add value to the product or service. Woon Kian et al. (2010) reinforce the growing awareness of the value of e-marketing and its impact on changes within the relationship between the consumer marketers and the consumer. Their findings support the belief that e-marketing improves business processes while strengthening the awareness in new markets of the organisation. The influence of the Internet and its tools can be seen in some form in virtually every business. Therefore, marketers need to take advantage of the opportunities offered by the Internet. With the Web, marketers can now embrace an electronic version of the marketplace. It allows provides a fresh sales channel, new methods of advertising, new ways of communicating, an innovative means of creating customer relationships. It has also facilitated the customisation of offerings to suit individual customers and helped improve service delivery. Marketers will have to prepare for the world of the new 'customer of power' of the digital era and learn how to use the marketing and communications tools of this era effectively. Digital marketing endeavours not only to provide information but to build and maintain customer relationships through online (digital) activities. Digital marketing is distinct because it is interactive and unique in nature. It rejects the one message fits all philosophy of mass media communication. With digital 
marketing, information is collected using sophisticated multimedia channels, which encourage customer interaction and feedback (Koekemoer, 2011).

Hsu and Yang (2013) explain how marketing has evolved over time. It has transformed in terms of content, focus and boundaries. Specifically, the development of the Internet has seen marketing move from being focussed on transactions to being more in favour of relationships. Furthermore, marketing is now network centred rather than market oriented with a major focus on customers and creating what they need and want. More recently, the deployment of Web 2.0 technologies, such as social networking sites, wikis, and blogs, has made relationship marketing (RM) even more viable. Du Plessis et al. (2010) explain that in order to cultivate an integrated style of marketing, interactive e-communication tools must be used. Marketers must keep in mind that consumers will use any media that is convenient to communicate access and transact with the organisation. The benefit of the Internet, SMSs, blogging, social networking sites and the Worldwide Web is that communication is interactive and not limited by physical and time constraints. The extensive access to information, social networking and better communication that its consumers, society at large and businesses enjoy is possible because of the Internet and virtual communities. Therefore, social networks can be described as websites, which connect millions of users worldwide who share the same interests, opinions and pastimes. Blogs, podcasts, social networks, bulletin boards, and wikis are used to communicate and share ideas about a given product, service, or brand and to interact with other consumers who have objective information about these offerings (Ioanăs and Stoica, 2014).

According to du Plessis et al. (2010) by using the Internet as an e-communication tool, organisations have a chance to build relationships and experiences for the consumer. This tool is interactive and has a world-wide reach, which makes it ideal for consumers to interact with the brands, and this allows consumers to create a perception of these brands. The Internet cannot be used on its own and should be combined with all other media to facilitate a constant and collaborative brand message. The continuity, immediacy, world-wide coverage, depth and interactive nature of the Internet offer outstanding communication opportunities. Berndt and Tait (2012) explain that websites can facilitate home purchasing, thus making the shopping experience easier for busy or working home keepers; enable customers to lodge complaints and provide other feedback on the company; allow customers to access a wide range of information about the company and its products; allow customers to track deliveries; provide customers with links to a wide range of supporting information to enable them to make the right purchase decision; keep customers informed about special offers, events, new products, withdrawn products and other related information; enable customers to view their accounts and make account payments; allow customers to have contact with the company wherever they are; access purchase policy information, warranties, guarantees, contact details, company location and opening hours and create a community where customers can share experiences and communicate with others to learn about the company and product.

Social media is made up of all the actions and practices between groups of people who collect and share information and opinions online. This is called conversational media. Conversational media uses web-based applications to create and deliver content in the form of words, pictures, videos. Therefore, social media is about sharing information, experiences, and views. New web technologies have made it easy for people to create and distribute their own content. Social media is characterised by participation, openness, conversation, community, and connectedness (Alkhoms and Alnsour, 2013). Ioanăs and Stoica (2014) explain that the most important role of social media is that it has transformed the manner in which marketers and consumers communicate. We live in an informational society and this affects the consumer decision processes and product evaluations. With social media, consumers have a new medium to get product information through peer communication. Additionally, by using social media, consumers also have the power to influence other buyers through their own product reviews and commentary on services used. Consumers are also influenced by other psychosocial characteristics like: income, purchase motivation, company presentation, company or brand's presence on social networks, demographic variables (age, sex and disposable income), workplace, method of payment and type of stores (online or physical). 


\section{Methodology}

This study was descriptive, cross-sectional and quantitative in nature. According to Iacobucci and Churchill (2010) a descriptive research study describes the rate of occurrence of something or the relationship between two variables. This study is cross-sectional in nature since information is gathered from the sample population at a given point in time. With a cross- sectional study, a description of the variable is specified at a particular point in time and the sample characterises the target population. For this study, data was collected from 440 individual mobile phone users who were representative of mobile phone users in KwaZulu-Natal [KZN], one of the largest provinces in South Africa. KZN is divided into 11 municipal districts. The researcher usedquota sampling to ensure that the respondents in KZN were suitably represented in the study. Clow and James (2014) explain that the purpose of a quota sample is to make sure that the sample contains the same number of the characteristics identified by the researcher and it is apparent in the population being studied. Individual mobile phone users were chosen using convenience sampling based on accessibility of respondents to the researcher. A questionnaire was used to gather data from the respondents.

\section{Results}

Biographical Details: The respondents' biographical details showed that the majority of the respondents (29\%) were in the age category 18 to $25,27 \%$ were in the age category 26 to $35,20 \%$ were in the age category 36 to $45,17 \%$ were between 46 and 55 years with $6 \%$ being between 56 and 65 years and 2\% were over 65 years old. There were more females than males ( $62 \%$ and $38 \%$ respectively). In terms of gender, the majority of the respondents (46\%) were Asian/Indian, $43 \%$ were Black, $6 \%$ were Coloured, $4 \%$ were White and two respondents indicated "other". On the issue of highest education level, $41 \%$ of respondents indicated that they had a diploma or degree, $35 \%$ have passed matric while $11 \%$ have a qualification below matric, $10 \%$ have a Honours/BTech qualification, and 3\% have a Masters qualification while only three respondents had a PhD. Respondents were questioned about how long they have been a mobile phone user. The majority (36\%) indicated 6 to10 years, followed by $27 \%$ who indicated 11 to 15 years, 22\% indicated more than 15 years, while $15 \%$ indicated 0 to 5 years. $68 \%$ of respondents have their mobile phone for personal use, $3 \%$ for business use and $29 \%$ indicated that they used their mobile phone for both personal and business purposes.

Smartphone ownership: $67 \%$ of the respondents indicated that they owned smartphones while 33\% do not own a smartphone. This result correlates with the report by Goldstuck (2014) which states that there were 14.5 million smartphones users by the end of December 2013 - MTN had 7.3 million active smartphone users while Vodacom had 7.2 million active smartphone users. That translates to about one smartphone for every 3.8 active accounts reported by the two networks. Between them, these two networks have about 55 million connections. The implication for the service provider is increased revenue from both the purchase and use of the smartphone. For business, it means that customers can communicate more directly with the business, access information more easily and demand responses more aggressively.

Type of customer: $52 \%$ of the respondents were prepaid customers and $48 \%$ were contract customers. Linked to this are the results of the infoDev study on use of mobile phones in South Africa, which found that the majority of people from the low-income groups are on prepaid mobile phones considering that these are cheaper than having contracts. In 2012, only $4 \%$ of low-income users living in rural areas had a contract phone, compared with $11 \%$ from the same income group in urban areas (SouthAfricaWeb 2014).

Current service provider: The majority of the respondents (38\%) are currently with MTN followed by 35\% who are with Vodacom, 22\% with Cell C, 3\% of respondents being subscribed to Telkom and 2\% with 8ta. The study conducted by Molapo and Mukwada (2014) revealed that the level of customer satisfaction varied significantly amongst cell phone network providers in South Africa, ranging from $63 \%$ for Vodacom to $5 \%$ for 8ta. This result could be attributed to 8ta being a newcomer to the cell phone industry, while Vodacom is already well established. MTN has the largest market share in the industry but the second lowest level of satisfaction. The majority of the respondents (32\%) have been with the same service provider for 4 to 6 years, $28 \%$ for more than 10 years, $23 \%$ for 1 to 3 years and $17 \%$ for 7 to 9 years. Number portability was introduced in 2006. This could be one of the reasons why respondents could have changed their service 
provider. $62 \%$ of respondents did not change their service provider while $38 \%$ did. This could suggest that the majority of respondents were satisfied with their current service provider.

Use of e-communication by service providers: $91 \%$ of respondents believed that their service provider used e-communication, $2 \%$ of respondents did not believe that their service provider used e-communication and $7 \%$ were unsure in this regard. $41 \%$ of the respondents felt that using e-communication was an excellent idea, $28 \%$ felt it was a very good idea, $22 \%$ indicated that it was a good idea, while $9 \%$ remained neutral in this regard. There was zero response for it being a bad idea or a terrible idea. This suggests that ecommunication was very well received by respondents.

Reasons for changing service provider: $38 \%$ of the respondents indicated that they did change their service provider. The reasons indicated were poor network coverage as indicated by $50 \%$ of the respondents, being very expensive (38\%), poor service (30\%), dissatisfaction (22\%), unreliable service (11\%), untrustworthy (2\%), three respondents indicated it was because of poor communication and one respondent cited ineffective advertising.

Methods of e-communication used by service providers: The majority of the respondents (91\%) indicated that their service provider uses e-communication. When asked which mediums are used for ecommunication, respondents indicated SMS (83\%), e-mail (50\%), internet (16\%), MMS (13\%), SNSs (11\%), websites (8\%) and blogs (3\%). 15\% indicated that all the mediums mentioned were used, as reflected in Table 1. It is clear that service providers need to use the internet, MMS, SNSs, their websites and blogs to a greater effect. Most owners use their mobile devices for more than simply phone calls. On average, $76 \%$ of users in emerging and developing markets indicated that they have used their cell phones to send text messages in the past 12 months. In the Philippines, Venezuela, Indonesia and South Africa, more than 95\% of cell phone owners indicated that they text regularly (Pew Research Center 2015).

Table 1: Multiple response of how service providers are perceived to use e-communication

\begin{tabular}{lll}
\hline & n & Percentage \\
\hline SMS & 331 & 83 \\
MMS & 50 & 12.5 \\
E-mail & 199 & 49.9 \\
Blogs & 13 & 3.3 \\
Internet & 64 & 16.0 \\
Website & 32 & 8 \\
Social Networking Sites (SNSs) & 44 & 11 \\
All of the above & 58 & 14.5 \\
Total & 791 & 198.2 \\
\hline
\end{tabular}

Respondents' feelings about their service provider using e-communication: When asked how they feel about their service provider using e-communication, the majority of the respondents (44\%) replied that it was more efficient and effective, faster to use and a time-saving way of communicating. $34 \%$ indicated that it was convenient to access anytime, $6 \%$ indicated that it was not applicable to them. A further $6 \%$ indicated that it was used for promotions/information while $5.5 \%$ considered it to be an annoyance. $4 \%$ were indifferent while less than $1 \%$ of respondents preferred calls, as shown in Figure 2. 
Figure 2: Respondents' feelings about their service provider using e-communication

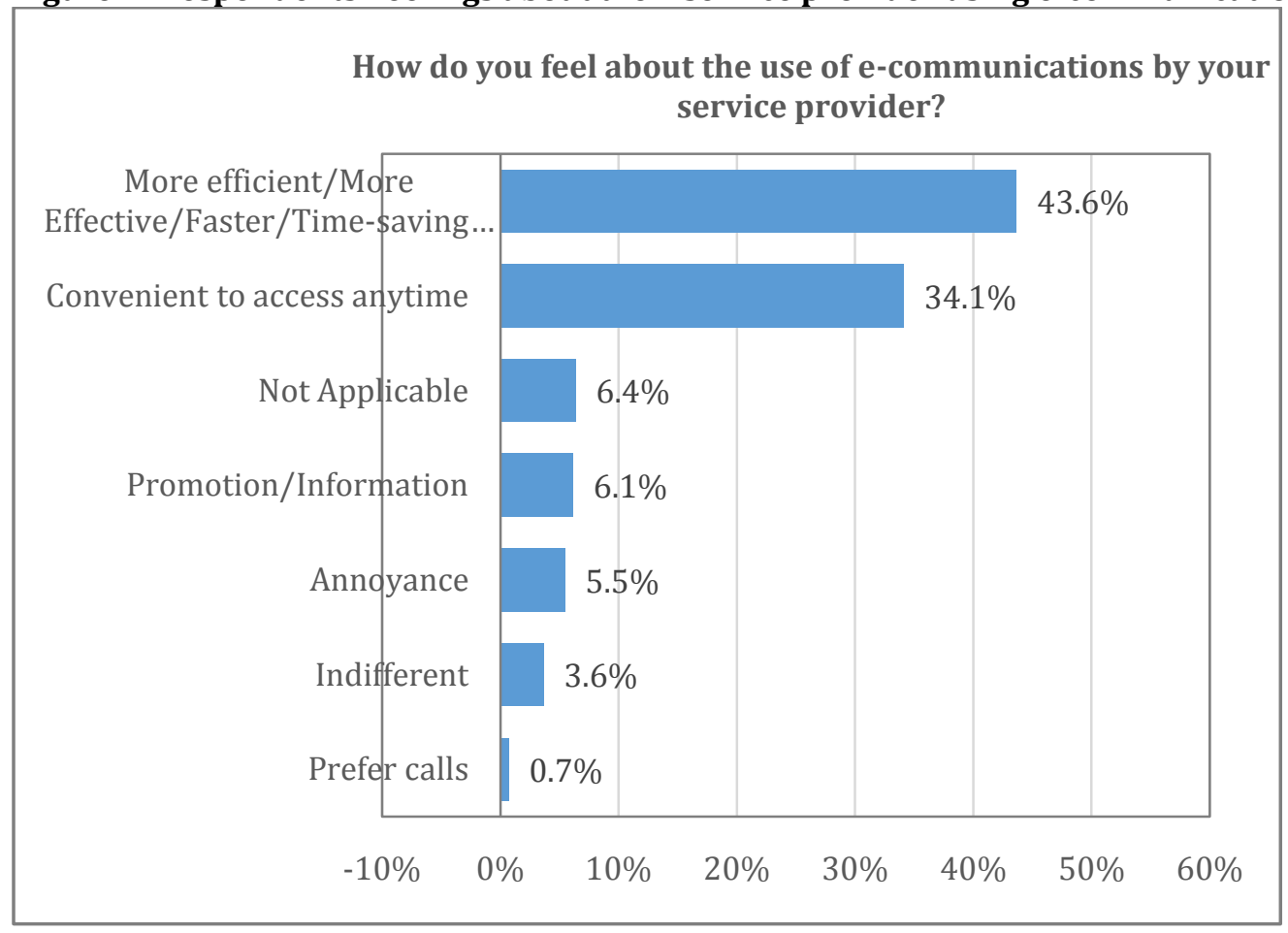

The relationship between the variables: It emerged that there were no significant differences between the dimensions of trust, loyalty and commitment, and length of time as a user ( $p>0.05)$. The analysis also examined the relationship between trust, loyalty and commitment and use of mobile phone (business use, personal use and both). The results yielded no significant relationship between usage and the dimensions of trust, loyalty and commitment ( $p>0.05)$. The results also indicated significant differences between those who changed their service provider and those who have not, for the dimensions of loyalty $(p=0.014)$ and commitment $(p=0.001)$, but not for the dimension of trust $(p>0.05)$. It also emerged that there was a significant relationship between the use of e-communication and the three dimensions: trust $(p=0.002)$, loyalty $(\mathrm{p}=0.005)$ and commitment $(\mathrm{p}=0.008)$.

\section{Conclusion}

This paper examined the relationship between e-communication and customer satisfaction in the mobile telecommunications industry in South Africa. It found that the use of e-communication by the service providers in the telecommunications industry did lead to greater customer satisfaction. The majority of the respondents indicated that e-communication assisted in making service providers more efficient and effective. This was because e-communication provided a faster way of communicating that saved time and was convenient to access anywhere. The results also showed that service providers used e-communication primarily to communicate with their customers and for advertising and promotions in general. SMS, e-mail and the internet emerged as the most popular tools of e-communication. The results suggest that by using the various e-communication tools, service providers are able to establish trust, loyalty, and commitment and improve communication with their customers in the mobile telecommunications industry. Furthermore, by focussing on these relationship marketing variables, these service providers can improve satisfaction, which will help to retain customers and ultimately maintain a long term relationship with them. By building trust, loyalty and commitment and improving communication, service providers are contributing towards customer satisfaction. This in turn leads to creating and maintaining long-lasting relationships with customers. 


\section{References}

Alkhoms, A. \& Alnsou, M. S. (2013). Social Media Marketing and Relationship Quality: Zain Jordan customers' perspective. European Journal of Business and Management, 5(25), 111-117.

Assaad, W., Gómez, J. M. \& von Ossietzky, C. (2011). Social Network in marketing (Social Media Marketing) Opportunities and Risks. International Journal of Managing Public Sector Information and Communication Technologies, 2(1), 13-22.

Berndt, A. \& Tait, M. (2012). Relationship Marketing and Customer Relationship Management. (3rd Ed), Cape Town: Juta.

Bolton, R. N. (1998). A Dynamic Model of the Duration of the Customer's Relationship with a Continuous Service Provider: The Role of Satisfaction. Marketing Science, 17, 45-65.

Bolton, R. N. \& Lemon, K. N. (1999). A Dynamic Model of Customers' Usage of Services: Usage as an Antecedent and Consequence of Satisfaction. Journal of Marketing Research, 36, 171-86.

Boohene, R. \& Agyapong, G. K. Q. (2011). Analysis of the Antecedents of Customer Loyalty of Telecommunication Industry in Ghana: The Case of Vodafone (Ghana). International Business Research, 4 (1), 229-240.

Buttle, F. (2004). Customer Relationship Management: Concepts and Tools. Amsterdam: Elsevier

Chipp, K. \& Ismail, Z. (2012). e-Commerce a Southern African perspective. Pretoria: Van Schaik Publishers.

Clark, M. \& Melancon, J. (2013). The influence of social media investment of relational outcomes: A relationship marketing perspective. International Journal of Marketing Studies, 5(4), 132-142.

Clow, K. E. \& James, K. E. (2014). Essentials of Marketing Research: Putting Research into Practice. Los Angeles: Sage.

du Plessis, F., van Heerden, N. \& Cook, G. (2010). Integrated Marketing Communication (3 ${ }^{\text {rd }}$ ed), Pretoria: Van Schaik Publishers.

du Plessis, P. J., Strydom, J. W. \& Jooste, C. J. (2012). Marketing Management (6 $6^{\text {th }}$ d), Cape Town: Juta.

Ercis, A. \& Rasouli, R. (2013). Influence of Relationship Marketing on Customer Satisfaction and Relationship Quality: The Case Study. Journal of American Science, 9(5), 12-21.

Giannini-Jr, G. T. (2010). Marketing Public Relations: A Marketer's Approach to Public Relations and Social Media. Boston: Pearson.

Goldstuck, A. (2014). SIGNPOST: Smartphones to rule the continent. Available at: http://www.bdlive.co.za/opinion/columnists/2014/03/09/signpost-smartphones-to-rule-thecontinent (Accessed: 15 August 2015).

Gummesson, E. (1999). Total Relationship Marketing: Experimenting with a synthesis of research frontiers. Australasian Marketing Journal, 7(1), 72-85.

Gummesson, E. (2004). Return on relationships (ROR): The value of relationship marketing and CRM in business to- business contexts. Journal of Business and Industrial Marketing, 19(2), 136-148.

Hamidi, A. \& Safabakhsh, M. (2010). The impact of information technology on E. Marketing. Procedia Computer Sciences, 3, 365-368.

Hanna, R., Rohm, A. \& Crittenden, V. (2011). We're all connected: The power of the social media ecosystem. Business Horizons, 54, 265-273.

Harridge-March, S. (2004). Electronic marketing, the new kid on the block. Marketing Intelligence \& Planning, (online), 22(3), 297-309. Available at: http://www.emeral dinsight.com/02634503.htmDOI10.1108/02634500410536885 (Accessed: 20 May 2015).

Harris, E. K. (2014). Customer Service: A Practical Approach (6 ${ }^{\text {th }}$ Ed), Harlow: Pearson.

Hsu, C. \& Yang, S. O. (2013). Achieving Online Relationship Marketing via Tourism Blogs: A Social Network Perspective. Pacific Asia Journal of the Association for Information Systems, 5(4), 1-25.

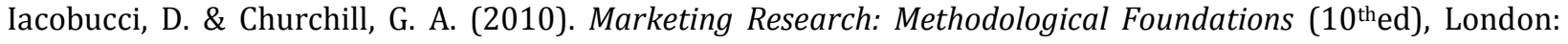
South-Western Cengage Learning.

Ioanăs, E. \& Stoica, I. (2014). Social Media and its Impact on Consumers Behaviour. International Journal of Economic Practices and Theories - Special issue on Marketing and Business Development, 4(2), 295303.

Johnston, R., Clark, G. \& Shulver, M. (2012). Service Operations Management: Improving Service Delivery (4thed), Harlow: Pearson.

Koekemoer, L. (2011). Introduction to Integrated Marketing Communications. Cape Town: Juta. 
Krishna, A., Dangayach, G. \& Jain, R. (2011). A Conceptual Framework for the Service Recovery Paradox. The Marketing Review, 11(1), 41-56.

Marchese, J. (2007). Defining social media. Media Post. Available: http://www.mediapost.com/publications/?fa=Articles.showArticle\&art_aid=61442 (Accessed: 6 April 2015).

MEAM Marketing. (2013). Available at http://www.meammarketing.com/advantages-and disadvantages-ofelectronic-communication/ (Accessed: 13 May 2015).

Mersey, R., Davis, T., Malthouse, E. \& Calder, B. (2010). Engagement with Media. Journal of Media Business Studies, 7(2), $39-56$.

Molapo, M. E. \& Mukwada, G. (2014). Does Customer Retention Strategies Matter in the South African Cellphone Industry? Mediterranean Journal of Social Sciences, 5(23), 144-151.

Ndubisi, N. O., Malhotra, N. K. \& Wah, C. K. (2009). Relationship marketing, customer satisfaction and loyalty: a theoretical and empirical analysis from an Asian perspective. Journal of International Consumer Marketing, 21(1), 5-16.

Ndubisi, N. O. (2004). Understanding the Salience of Cultural Dimensions on Relationship Marketing, its Underpinnings and Aftermaths. Cross Cultural Management, 11(3), 70-89.

Pew Research Center. (2015). Internet Seen as Positive Influence on Education but Negative on Morality in Emerging and Developing Nations. Available at: http://www.pewglobal.org/2015/03/19/1communications-technology-in-emerging-and-developing-nations/ (Accessed: 21 August 2015).

Rizan, M., Warokka, A. \& Listyawati, D. (2014). Relationship Marketing and Customer Loyalty: Do Customer Satisfaction and Customer Trust Really Serve as Intervening Variables? Journal of Marketing Research and Case Studies, 2, 1-12.

Sloan, L. (2014). The future of communicating in a digital space: Enhanced user experience through integrating elements. Available: http://www.bizcommunity.com/Article/196/78/116322.html (Accessed: 25 August 2014).

South African Social Media Landscape report. (2015). Available at: www.worldwideworx.com. (Accessed: 15 August 2015).

SouthAfricaWeb. (2014). South Africans and their cell phones. Available: http://www.southafricaweb.co.za/article/south-africans-and-their-cell-phones (Accessed: 19 August 2015).

Sri-Jothi, P., Neelamalar, M. \& Shakthi-Prasad, R. (2011). Analysis of social networking sites: A study on effective communication strategy in developing brand communication. Journal of Media and Communication Studies, 3(7), 234-242.

Staff writer. (2015). Study reveals African mobile phone usage stats. Available at: http://www.itnewsafrica.com/2015/04/study-reveals-african-mobile-phone-usage-stats/ (Accessed 21 May 2015).

Stelzner, M. (2009). Social Media Marketing Industry Report. How marketers are using social Media to grow their business? www.whitepapersource.com.

Stokes, R. (2011). E-marketing: the essential guide to digital marketing. $4^{\text {th }}$ ed. Cape Town: Quirk Education.

Stokes, R. (2011). eMarketing: The essential guide to marketing in a digital world ( $5^{\text {th }} \mathrm{ed}$ ), Quirk eMarkerting

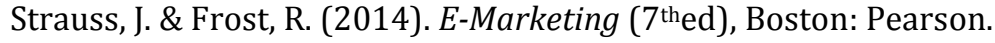

The Mobile Economy: Sub-Saharan Africa Report. (2014). Available at http://www.gsmamobileeconomyafrica.com/.

Theodosiou, M. \& Katsikea, E. (2012). Antecedents and performance of electronic business adoption in the hotel industry. European Journal of Marketing, 46(1), 258-283

Woon-Kian, C., Shafaghi, M., Woollaston, C. \& Lui, V. (2010). B2B e-marketplace: an e-marketing framework for B2B commerce. Marketing Intelligence \&Planning, 28(3), 310-329.

Zabin, J. (2009). The ROI of Social Media Marketing: Why it pays to drive word of Mouth. Aberdeen Group. www.adberdeen.com.

Zeithaml, V. A., Bitner, M. J. \& Gremler, D. D. (2013). Services Marketing: Integrating customer focus across the firm ( $6^{\text {th }}$ ed), New York: McGraw Hill. 